\title{
The Development of Web-Based Learning Models as A Learning Medium for Students of Audio Video Electronics Competencies
}

\author{
Dedy Hendriana, Rufi'i, Hartono \\ Educational Technology, PGRI Adi Buana University, Surabaya
}

\section{Edcomtech}

\author{
Jurnal Kajian \\ Teknologi Pendidikan \\ Volume 6, No 1, April 2021 \\ 100-109
}

Submitted 12-05-2020

Accepted 03-06-2020

Corresponding Author

Dedy Hendriana

dedyhendriana123@gmail.com

\section{OPEN

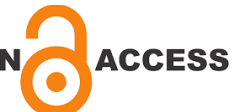

\begin{abstract}
At present distance education has reached almost the entire archipelago. These developments occur a lot in higher education. This benefit is also brought about in secondary education, as seen in SMKN 1 Jetis, especially in the electronics field. Web media with URL ruangpakdedy.com was developed to answer the many electronic learning materials in cyberspace but are still scattered, so the web is made to collect various electronic material sources in one site. This ease is expected to increase skills that have a greater portion than cognitive knowledge in vocational education. The development used refers to the $4 D$ Thiagarajan model by going through the planning process, material testing by material experts, media testing by media experts, revisions, and products tested on students with good results. As a complement on the web also added assignments that are connected to the LMS page and quiz.
\end{abstract}

Keywords: Development Research, Learning Medium, Electronics Competencies, Web-based Learning Model

\section{INTRODUCTION}

Based on the understanding of the National Education System which states that the curriculum is a teaching and learning design program that can be used as a guide by educators to achieve educational goals, then there are two dimensions of the curriculum, the first is a plan that includes objectives, content, and learning material. In contrast, the second is related to the method used for learning activities. In this case the curriculum is not meant simply a set of materials that must be given or mastered by students, but also includes everything that happens in the learning process. To achieve the specified educational goals, a vehicle is needed that can be realized into a media. Thus appropriate learning is an educational activity that uses the right media to achieve the stated goals. Success in achieving educational goals depends a lot on the learning process in class designed by the instructor in preparing the development of attitudes, knowledge, and skills.
The learning process generally consists of instructors who are the main subjects in shaping their student personality. Usually, the learning process is done rigidly, dogmatically and more deadly to creativity, because the process is a traditional learning process that does not provide a space for creativity, talents and abilities hidden within students. The learning process is a communication process that is realized through the activity of delivering information to students. Information conveyed can be in the form of knowledge, expertise, skills, ideas, experiences, etc. The information is usually packaged as a single unit, teaching material. According to (Kunandar, 2007), learning-oriented mastery of the material is considered a failure to produce active, creative, and innovative students. Therefore, there needs to be a change in learning approach that is more meaningful and more empowering for students to equip students in facing life problems faced now and in the future. 
The development of information technology has achieved rapid development, and requires that learning be integrated with the web to develop students' higher-order thinking skills. Besides this integration will develop student skills where computers have controlled almost all work fields in the world. Just like other fields, information technology is also directly related to the world of education. The influence of its development has a positive impact, namely the more open and spread of information and knowledge from and worldwide through space and time. In line with the opinion of (Usta, 2011), the advantage of this learning model is that learning can be done anywhere and anytime.

The development of information technology often leads to distance learning. Distance education is the scope of formal education where the learning model has the characteristics of the learning actors, namely between students and instructors in separate locations. In practice this learning is not like conventional learning that does direct learning face to face, it has more benefits (El-Seoud, El-Sofany, \& Karam, 2015)and 2. Based on Virendra Gawande's findings, direct learning without face-to-face is significantly influenced by Competitive and Facilitator styles, but not by the gender, age, and computer experience of students (Gawande, 2015).

In the subject of electronics has the characteristics of learning that requires more demands on the material aspects of the skills/psimototrik. Vocational students tend to be directed into the world of work after graduation compared to high education. Stigma like this makes the challenge for the material in electronic subjects which incidentally is needed reliable skills.

In direct face-to-face learning, the teacher automatically acts as an instructor who provides demonstrations in the work of an electrical circuit, such as troubleshooting on an electronic device. But in distance education, students will tend to look for these references with search engines whose results can be very random. Another obstacle is that most of the references use English which students do not understand. Likewise, if a reference is obtained from a visual provider, YouTube, for example, it takes multiple channels to get material that is truly as expected. Challenges to research problems generally relate to solving practical problems in the field. This can be done by verifying a design or design, strategy, or learning model (Putra, 2012). Electronics competencies is a vocational secondary education department that prepares graduates to become electronic technicians. Fields of work that can be taken for example are operating, maintaining, installing, implementing, and repairing electronic systems, operators in electronics companies, and working in electronics companies owned by government agencies and private companies.

As it is known that face-to-face learning requires teachers and students' presence in the same time and place. Meanwhile, to improve students' knowledge and skills, more time is needed to do experimental exercises. Therefore a mixed learning program is needed that can include several forms of learning tools. The use of the web for example, in formal learning (Hamad, 2015)blended learning approach has developed through the last two decades, however it is not a preference for many teachers and students, the researcher of this study used the quantitative experimental method. The sample of this study was two sections (30 students each. According to Licks web applications can increase interest in the potential of its users. This can be done by providing collaboration in the form of feedback. Providing web features requires users to provide feedback needed to improve web capabilities (Licks, Teixeira, \& Luyten, 2018)home to activities such as fabrication processes and Do-It-Yourself (DIY. Web users can result in a good environment, for example innovative learning and learning variations. It deals with the concept of practical communities, creative learning, peer-to-peer learning, and personal learning, thus creating a formal and informal education environment (Prasojo et al., 2020). Also, webbased learning systems can use project-based learning. Of course this will improve the 
construction of creative skills (Chatwattana \& Nilsook, 2017). Psychologically, learning will bring about behavior change. Changes in behavior occur as a result of interactions with the environment due to meet the needs of life (Slameto, 2010). Based on these opinions, the authors develop web-based media in the application of distance learning to provide a flexible media, anytime and anywhere can be accessed, but it can also improve student skills by independent learning.

According to its classification, the media can be divided into 3 namely auditive media, visual media, and a combination of both (Sanjaya, 2010). Web-based learning media that have visuals in it have an important role in the learning process, namely facilitating understanding and strengthening memory. Visuals can also foster student interest and provide connections between subject matter and the real world. More effectively, there is an interaction with the visual to ensure the information transfer process. Development research with the title The Development Of Web-Based Learning Models As A Learning Medium For Students of Audio Video Electronics Competencies uses the web to collect all electronic material both material in the form of theory and practicum in one site. The web that functions as a learning medium has aroused curiosity and interest in new things, arousing motivation, and further impacts are psychologically influential (Arsyad, 2011). The ease of searching for learning materials is the main purpose of the construction of this website.

Following some research conducted on the use of the web in education, the web can function appropriately in learning outside the classroom. The CMS method is proven to effectively solve distance teaching problems (Mohorovi, Tijan, \& Čišić, 2010). The web can also be used as one of the training content (Guetl, Chang, Edwards, \& Boruta, 2013)socially interactive in nature, have much to contribute to the area of Computer Assisted Language Leaning. Unfortunately, Web 2.0 technologies for the most part have been used in an ad hoc manner, permitting language learners acquire knowledge through interaction, but not through a more structured manner as these technologies were not developed to help lean languages as such. The goal of our work is to research and develop an environment, which employs Web 2.0 technology plus online language learning tools to provide a more integrated language learning environment. This paper will explore the technologies and provide information about how tools can be better integrated to provide a more productive working environment for language learners. A first working proof of concept based on our approach introduced is promising supporting modern language requirements and first findings and space for improvements are discussed.","container-title":"International Journal of Emerging Technologies in Learning (iJET. The addition of content according to the user or User Interface (UI) helps achieve the goal of delivering learning material (Choi, Choe, \& Oh, 2013)"container-title":"International Journal of Emerging Technologies in Learning (iJET. Web technology can be used as a modern application that is needed routinely and in learning (Batsila, Tsihouridis, Vavougios, \& Loannidis, 2015). Even as an educational tool, the web can expand and deepen knowledge (Faizi, Chiheb, \& Afia, 2015).

\section{METHOD}

Development research with the title The Development Of Web-Based Learning Models As A Learning Medium For Students Of Audio Video Electronics Competencies arch is a research development that produces a product in e-learning media in the subject of Electronics for class X, XI, and XII students. The author's development model is the 4D Thiagarajan model that has Define, Design, Develop, and Disseminate procedures. Each stage is a systematic sequential steps to get media that has a good level of eligibility. Except Disseminate, the other three steps are taken by the author. The Define Phase determines the conditions for which a media can be used. This stage produces a web design after going through initial analysis, in concept analysis and student analysis. Then the Design stage prepares a learning tool in the form of media. 
At the Develop stage it produces learning media that experts have previously validated. In a research development entitled The Development Of Web-Based Learning Models As A Learning Medium For Students Of Audio Video Electronics Competencies the author uses material experts and media experts. To provide validation to the media material experts is used to validate the content of learning materials and media experts to validate learning media and learning design.

Material expert validates 3 aspects namely Material content, Technology, and Message Design. Material content aspects include: Accuracy of material content following basic competencies in the National Curriculum, Completeness of material content following the syllabus, Clarity of material description following Indicators of Competency Achievement, Extent of coverage according to Competency Standards, and Clarity of examples in each material. Technology aspects include: youth access by users using laptop/ smartphone devices, the quality of technology following the hardware operating system, technology updates by IT development, the relevance of the material to the learning strategy, and no error in the button. Message Design Aspects include: Presentation of the text by the material, Components of the image are easy to understand, Video tutorials are clear, Sounds on video tutorials are clear, and Every web page is well connected. Each aspect has 5 question points so that the total number of question points given to the material Expert is 15 pieces.

Media Expert validated 2 aspects related to learning design, namely Technology and Message Design. In technology, media experts have the same question points with material experts, as many as 5 pieces. Message Design aspects include: Appropriate font selection, background color does not interfere with the material, Indonesian following EYD, clear audio volume, and application features can be run. In total there are 10 question points.

After validation by the material expert and media expert, web media in the online form are ready to respond from teachers and students. The teacher who was asked to respond as many as 5 people is a writer in the Electronics MGMP. The five people are teachers in charge of electronics subjects in SMK 1 Jetis as many as 3 people and 2 people from SMK 1 Madiun City. A total of 10 question points were asked including: Appropriateness of the material with IC / KD, Appropriateness of the video to clarify the material, Appropriateness of the questions with the material, Presentation of sequential and systematic material, Use of language that is easily understood, Clarity of media usage instructions, Level of interactive learners with the media, Media can be used as an alternative to independent learning, the suitability of images to clarify the material, and the availability of summaries on each material.

While the response for students as many as 34 students in class XI Audio Video is where the author teaches. The points for which the response was asked included questions related to the convenience of learning and the accuracy of students' material when using the web as a medium. The question points include: Clarity of image display, Clarity of video display, Clarity of sound, Color combination of display, The type of font used is clear and easy to read, Conformity of video with teaching material, Presence of navigation buttons on media, Material presented is equipped with practice exercises, The use of Indonesian following EYD, and interactive learning media can be used anywhere.

The data's technical analysis uses 4 scales, divided into 4 weight values, 4 values for the Very Good category, 3 values for the Good category, value 2 for the Poor category, and a value of 1 for the Very Poor category. Technical analysis of the data is presented in Table 1. Criteria for Rating Scale (Widoyoko \& Putro, 2012).

Table 1. Criteria for Rating Scale

\begin{tabular}{cc}
\hline Value Weight & Category \\
\hline 4 & Very worthy \\
\hline 3 & Worthy \\
\hline 2 & Not worthy \\
\hline 1 & Very bad \\
\hline
\end{tabular}


From the validation of material experts, media experts, peer testing and student responses, the sum of all question points is determined. The sum of each validator is converted as a percentage. Percentage calculation uses the following formula:

$$
P=\frac{F}{n} \times 100 \%
$$

\section{Information:}

$P$ : Percentage

$F$ : The total percentage of subjects

$\mathrm{n}$ : number of respondents

The percentage form is stated in descriptive terms to determine the appropriateness of the web media under study. Descriptive descriptions are divided into 4 categories: $A$, B, C, and D shown in Tabel 2.

Table 2. Eligibility Level Criteria

\begin{tabular}{llll}
\hline Category & Percentage & Qualification & Equivalent \\
\hline A & $80 \%-100 \%$ & Valid & Worthy \\
\hline & & Valid & Decent \\
B & $60 \%-79 \%$ & enough & enough \\
\hline C & $50 \%-59 \%$ & less valid & Inadequate \\
\hline & & & Not \\
D & $0 \%-49 \%$ & Invalid & feasible \\
\hline
\end{tabular}

\section{RESULT}

\section{Web}

Judging from its function, the web is categorized as a CMS. CMS or Content Management System is software that can manipulate both the content and appearance of websites. Web developers often use software that includes Moodle, Joomla, WordPress, Drupal, and various blogs. YouTube is also included in this mode. Likewise, virtual conferencing such as Cisco WebEx, for example, are also included in this mode. CMS mode is more often used to provide material. Generally we find sites paid or free with CMS mode used to promote a product, both commercial information and information for social media. This is why the CMS mode tends to be based on the interests of the maker / developer, in this case the teacher / educator can be said.

The LMS (Learning Management System) mode is built with the main objective for the world of Education, it is clear from the word "learning" which refers to learning. Sites included in the LMS mode include Moodle, Edmodo, Google Classroom, Khan Academy, Trello, and so on. The LMS mode characteristic is the format for assignments and assessments, which is very familiar to students' needs. Except Moodle, all views from LMS mode cannot be changed. Provision of material can only be done once in the desired class.

The lack of CMS mode which is less interactive and the lack of LMS that cannot put a lot of material as a reference that can be opened repeatedly, the authors responded to by building a web that combines them. The web developed by the writer brings together the two, both LMS and CMS. The platform used is WordPress because of the ease of manipulating its appearance. Writers use plug-in facilities with various widgets and templates to the maximum to get the most appropriate and attractive web appearance. While the LMS mode, the writer inserts on the "ASSIGNMENT" menu, which when clicked it will go to the Edmodo site automatically, where each class has been previously created.

In addition to other LMS functions, there is an assessment system. The author adds a QUIZ menu to access the quiz that students must follow. Embedding this LMS function is nothing but to facilitate student access, which the authors expect one web for all needs.

\section{Content}

As a reference point for material and practicum in electronics class $\mathrm{X}, \mathrm{XI}$, and $\mathrm{XII}$ at SMKN 1 Jetis, the web is designed and developed using Indonesian. Web names use words that are easy to remember. The author slipped the word "Pak Dedy" as a daily call at school, so be the URL in question is "ruangpakdedy.com". The main menu in the initial web appearance and the meaning are shown in Table 3. 
Table 3. Giving a name on the main menu ruangpakdedy.com web

\begin{tabular}{ll}
\hline MENU NAME & MEANING \\
\hline Home & Display front view of web pages \\
\hline Blog & An overall view of what was posted \\
\hline Software Electronics & Electronics application programs \\
\hline Video Tutorial & Video tutorial about the content of learning electronics practicum \\
\hline Penugasan & Giving assignments to students on edmodo \\
\hline Quiz & Tests / Evaluations with online exams by beesmart application \\
\hline Modul Elektronika Untuk SMK & 2013 curriculum electronics module for SMK \\
\hline Modul Elektronika Untuk & Electronics modules for the student level \\
\hline Mahasiswa & \\
\hline Electronics Store & Buying and selling electronic goods
\end{tabular}

Display the front view of the web is when the URL "ruangpakdedy.com" typed in the browser. On the main page displayed headlines and text themes. Some photos are displayed in slides alternately. The photos depict the author's activities as an electronics teacher at SMK 1 Jetis. The following picture is shown on the front page.

\section{Ruang Pak Dedy \\ Tempat Belajar dan Berbagi Materi \\ Elek:rcnika d STMK Negeri 1 Jeris \\ Mojnkerto - alawa Timur}

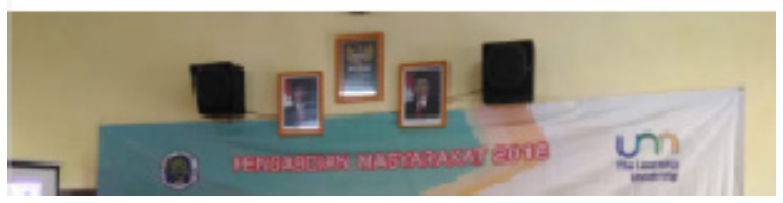

Picture 1. Display Home Web ruangpakdedy. com using smartphone

When selected, the Electronics Module menu will go to a page that is a collection of electronic material. The electronic module is made in PDF format. The module can be downloaded for free by anyone, whether Jetis own or public SMK vocational students. Simply by selecting "here" then the download will automatically be done and entered on the user's drive. The collection of material is shown in Figure 2.

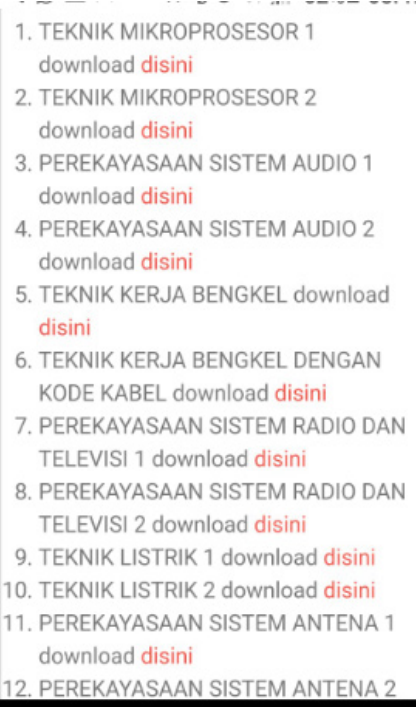

1. TEKNIK MIKROPROSESOR 1 download disini

2. TEKNIK MIKROPROSESOR 2 download disini

3. PEREKAYASAAN SISTEM AUDIO 1 download disini

4. PEREKAYASAAN SISTEM AUDIO 2 download disini

5. TEKNIK KERJA BENGKEL download disini

6. TEKNIK KERJA BENGKEL DENGAN KODE KABEL download disini

7. PEREKAYASAAN SISTEM RADIO DAN TELEVISI 1 download disini

8. PEREKAYASAAN SISTEM RADIO DAN TELEVISI 2 download disini

9. TEKNIK LISTRIK 1 download disini 10. TEKNIK LISTRIK 2 download disini PEREKAYASAAN SISTEM ANTENA 1 download disini 12. PEREKAYASAAN SISTEM ANTENA 2

\section{Picture 2. Collection of Webpakdedy.com Web modules}

On the "Assignment" page, users will go to a page containing various tasks on the web. By selecting one of the tasks, the user will be directed to the LMS page, Edmodo. The "Assignment" page is shown in Figure 3. 


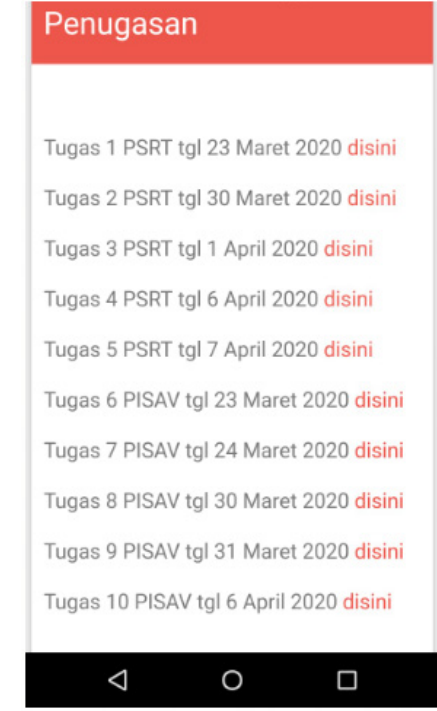

\section{Picture 3. "Penugasan" Web page ruangpakdedy.com}

As an interactive page, on the Web ruangpakdedy.com added the "Quiz" menu. This menu leads to an exam that runs online. Shown in Figure 4.

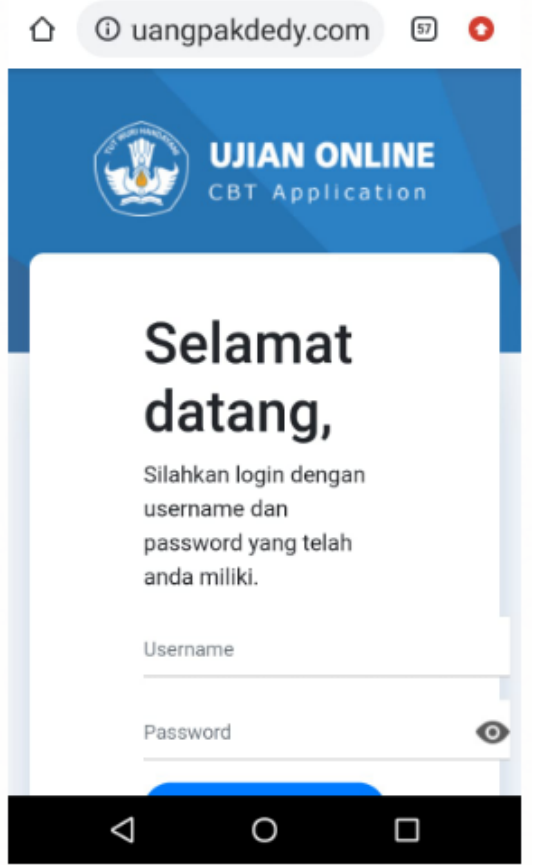

Picture 4. Web page "Quiz" ruangpakdedy. com

After the initial product has been developed, a trial consists of two stages: the expert test and small scale and large scale tests. The expert test includes material/ content experts and media experts while the small scale test is through a colleague of 5 electronics teachers and a large scale test is conducted with 34 student respondents in electronics namely students of class XI Audio Video Engineering.

In the research development under the title The Development Of Web-Based Learning Models As A Learning Medium For Students Of Audio Video Electronics Competencies, the results of product trials were obtained by validating material experts with 53 points, 34 points for media experts, 176 points for colleagues, and 1193 points for students. The results of the percentage and eligibility level of eligibility are shown in Table 4.

Table 4. Trial Results of ruangpakdedy.com Web Products

\begin{tabular}{llll}
\hline Respondents & $\begin{array}{l}\text { Total } \\
\text { score }\end{array}$ & Percentage & Qualification \\
\hline $\begin{array}{l}\text { Material } \\
\text { Expert }\end{array}$ & 53 & $88.33 \%$ & Worthy \\
\hline Media Expert & 34 & $85.00 \%$ & Worthy \\
\hline Peers & 176 & $88.00 \%$ & Worthy \\
\hline Student & 1193 & $87.72 \%$ & Worthy \\
\hline
\end{tabular}

The development research results with the title The Development Of Web-Based Learning Models As A Learning Medium For Students Of Audio Video Electronics Competencies can be illustrated in graphical form shown in Figure 5. It appears that the subject matter experts showed a percentage of $88.38 \%$, media experts were $85 \%$, colleagues were $88 \%$, and students were $87.72 \%$.

\section{WEB-BASED LEARNING FEASIBILITY PROSENTAGE}

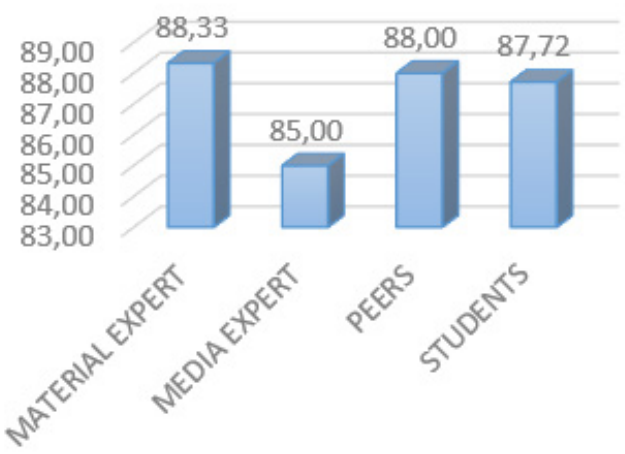

Picture 5. Graph of Test Results for Web Products ruangpakdedy.com 


\section{DISCUSSION}

A good media has a minimum qualification fair enough, meaning that the media is suitable for use with a few notes or revisions. The validation results with a percentage of at least $80 \%$ can be categorized as Eligible media. To get proper validation, a media does not necessarily be used directly by students but must go through a development stage with sequential and systematic development steps.

The 4D development model introduced by (Thiagarajan, Semmel, \& Semmel, 1974) as a stage of media development was used in the Development of Electric Subject With WebBased Learning Models research. According to (Mulyatiningsih, 2011), this development model can be used to research and develop teaching materials such as modules, worksheets, textbooks, and the media. The media can be widely used in society, the product needs to be analyzed and tested for its effectiveness (Sugiyono, 2003).

Based on the results of validation and testing, it can be seen that the web-based learning media on electronic productive subjects at SMKN 1 Jetis Mojokerto can be said to meet the validation or Eligible criteria. The validity of the web media is based on the validation of material experts and media experts. Peer trials and students' results on web-based learning media showed that teachers and students gave positive responses to every aspect assessed.

Web-based learning media that have been developed contain a wide variety of electronic material and are accompanied by the content of quizzes and quizzes that are integrated with online exams equivalent to CBT online exams on national exam evaluations. Students are expected to easily find information related to electronic media and familiarize them in computer-based exams or CBT.

The results achieved by using the web in learning media can be applied in all fields. Especially fields that require special skills. Because the web facilitates limited time and space on classroom learning. The web can be integrated as a resource for learning activities
(Lin, 2016). Likewise Wang's research results show that the web can improve distance learning quality (Wang, 2016). The use of the web both by students, students (JaimezGonzález \& Castillo-Cortes, 2020), teachers (Caliskan, Guney, Sakhieva, Vasbieva, \& Zaitseva, 2019) is felt to be very beneficial. Additional social media features embedded on the web are the main attraction for web users among young people (Linek, Schafrick, \& Tochtermann, 2013). Interestingly the web can be accessed by people with disabilities too (Shawar, 2015).

The LMS method as an assessment tool can be used as a learning tool (Kapsalis, 2009). Do in Development research with the title The Development Of Web-Based Learning Models As A Learning Medium For Students Of Audio Video Electronics Competencies using LMS with webpakdedy.com web services providing LMS its content.

In general, the advantages of web-based learning media that have been developed are the appearance of simple but quite elegant learning media, meaning that both the colors, fonts, layout of each item are not excessive but provide comfort for the user.

Another advantage of this web development is that it has a complete variety of material as student learning materials independently. These materials are integrated allowing students to have interesting learning experiences because they are more interactive and up-to-date. In addition to embedding LMS pages it should not be underestimated, that interactive assignments and quizzes help students in distance education. It can improve the ability to think in students (Kuswandi, Surahman, Thaariq, \& Muthmainnah, 2018) principles, investigation, decisions and represent products. This model is the right learning method used in various disciplines because it can improve thinking skills. This study aims to describe students' perceptions of the application of project-based learning models in the training program design and strategy courses by clustering data using the K-Means method. The result of the study shows that of the four clusters, they strongly agree, agree, disagree and strongly disagree, 
cluster 1 (agree.

It cannot be denied that this website has a weakness: the infrastructure of equipment that must be adequate. For students the use of internet data packages is still a major obstacle. In the future, the ease of cheap and comprehensive internet access is very much expected for everyone.

\section{SUMMARY}

Implementing distance education with web-based learning is felt to have several benefits for students and the teachers themselves. For students including effective learning objects, learning objects also allow for experience in problem solving, students can explore the material provided, so students can collaborate among others, on the other hand students will also learn independently in solving problems. As for teachers, learning materials can be used repeatedly, there are learning objects that can present material that might not be possible in face-to-face learning and innovative learning that can increase productivity.

\section{REFERENSI}

Arsyad, A. (2011). Media pembelajaran. Jakarta: PT Raja Grafindo Persada.

Batsila, M., Tsihouridis, C., Vavougios, D., \& Loannidis, G. (2015). Factors that Influence the Application of Web 2.0 Based Techniques for Instructional Purposes - A Case Study. International Journal of Emerging Technologies in Learning, 10(4), 15-21.

Caliskan, S., Guney, Z., Sakhieva, R., Vasbieva, D., \& Zaitseva, N. (2019). Teachers' Views on the Availability of Web 2.0 Tools in Education. International Journal of Emerging Technologies in Learning (IJET), 14(22), 70-81.

Chatwattana, P., \& Nilsook, P. (2017). A Webbased Learning System using Projectbased Learning and Imagineering. International Journal of Emerging Technologies in Learning (IJET), 12(05), 4-22.

Choi, Y., Choe, Y., \& Oh, T. (2013). Future Direction for Next Generation Web.
International Journal of Emerging Technologies in Learning (IJET), 8(6), 6-10.

El-Seoud, S. A., El-Sofany, H., \& Karam, O. (2015). Semantic Web Architecture and its Impact on E-learning Systems Development. International Journal of Emerging Technologies in Learning (IJET), 10(5), 29-34.

Faizi, R., Chiheb, R., \& Afia, A. E. (2015). Students' Perceptions Towards Using Web 2.0 Technologies in Education. International Journal of Emerging Technologies in Learning (IJET), 10(6), 32-36.

Gawande, V. (2015). Development of Blended Learning ModelbasedonthePerceptions of Students at Higher Education Institutes in Oman. International Journal of Computer Applications, 114, 38-45. doi: 10.5120/19946-1747

Guetl, C., Chang, V., Edwards, A., \& Boruta, S. (2013). Flexible and Affordable Foreign Language Learning Environment based on Web 2.0 Technologies. International Journal of Emerging Technologies in Learning (IJET), 8(2), 16-28. doi: 10.3991/ijet.v8i2.2488

Hamad, M. M. (2015). Blended Learning Outcome vs. Traditional Learning Outcome. International Journal on Studies in English Language and Literature, 3(4), 75-78.

Jaimez-González, C. R., \& Castillo-Cortes, M. (2020). Web Application to Support the Learning of Programming Through the Graphic Visualization of Programs. International Journal of Emerging Technologies in Learning (IJET), 15(06), 33. doi: 10.3991/ijet.v15i06.12157

Kapsalis, V. (2009). Implementation of an Assessment System Incorporating Web-based Parameterized Questions. International Journal of Emerging Technologies in Learning (IJET), 4(3), 20-28.

Kunandar. (2007). Guru Profesional Implementasi Kurikulum Tingkat Satuan Pendidikan (KTSP) dan Sukses dalam Sertifikasi Guru. Jakarta: PT Raja Grafindo Persada. 
Kuswandi, D., Surahman, E., Thaariq, Z. Z. A., \& Muthmainnah, M. (2018). K-Means Clustering of Student Perceptions on Project-Based Learning Model Application. 2018 4th International Conference on Education and Technology (ICET), 9-12. Malang, Indonesia: IEEE. doi: 10.1109/ICEAT.2018.8693932

Licks, G., Teixeira, A., \& Luyten, K. (2018). Smart Makerspace: A Web Platform Implementation. International Journal of Emerging Technologies in Learning (IJET), 13(02), 140-156.

Lin, W. (2016). Human Resources Management of Track and Field Web Course in College Physical Education. International Journal of Emerging Technologies in Learning (IJET), 11(4), 95-102.

Linek, S., Schafrick, A., \& Tochtermann, K. (2013). Just for the Image? The Impact of Web 2.0 for Public Institutions. International Journal of Emerging Technologies in Learning (IJET), 8(2013). Retrieved from https://www. learntechlib.org/p/45223/

Mohorovi, S., Tijan, E., \& Čišić, D. (2010). Using Web Content Management Systems in University E-Commerce Courses. International Journal of Emerging Technologies in Learning (IJET), 5(2). Retrieved from https:// www.learntechlib.org/p/44936/

Mulyatiningsih, E. (2011). Risetterapan bidang pendidikan dan teknik. Yogyakarta: UNY Press.

Prasojo, L., Habibi, A., Mukminin, A., Sofyan, S., Indrayana, B., \& Anwar, K. (2020). Factors Influencing Intention to Use Web 2.0 in Indonesian Vocational High Schools. International Journal of Emerging Technologies in Learning (IJET), 15(5), 100-118.
Putra, N. (2012). Research \& development penelitian dan pengembangan: Suatu pengantar. Jakarta: PT Raja Grafindo Persada.

Sanjaya, W. (2010). Strategi Pembelajaran Berorientasi Standar Proses Pendidikan. Jakarta: Kencana.

Shawar, B. A. (2015). Evaluating web accessibility of educational websites. International Journal of Emerging Technologies in Learning, 10(4).

Slameto. (2010). Belajar dan Faktor-Faktor yang Mempengaruhinya. Jakarta: Rineka Cipta.

Sugiyono. (2003). Metode Penelitian Administrasi Dilengkapi dengan Metode $R \& D$. Bandung: CV. Alfabeta.

Thiagarajan, S., Semmel, D. S., \& Semmel, M. I. (1974). Instructional development for training teachers of exceptional children. Minesota: The Council for Exepttional Children.

Usta, E. (2011). The Effect Of Web-Based Learning Environments On Attitudes Of Students Regarding Computer And Internet. Procedia - Social and Behavioral Sciences, 28, 262-269. doi: 10.1016/j.sbspro.2011.11.051

Wang, L. (2016). Personalized Teaching Platform Based on Web Data Mining. International Journal of Emerging Technologies in Learning (IJET), 11(11), 15-20.

Widoyoko, S., \& Putro, E. (2012). Teknik Penyusunan Penelitian. Yogyakarta: Pustaka Belajar. 